\title{
EUROPEAN CHEMICAL INDUSTRY COMPETITIVENESS: HISTORICAL TRENDS AND DEVELOPMENT PROSPECTS
}

\author{
Dmytro GLADKYKH ${ }^{1}$, \\ Donetsk National University (Vinnitsa), Ukraine
}

\begin{abstract}
The purpose of the paper is to analyze historical trends and development prospects of the European chemical industry competitiveness. It is concluded that the chemical industry is one of the EU's most successful spheres, boasting $€ 527$ billion in sales in 2013, making it the second-largest global manufacture. Methodology. To explain the competitiveness of the EU chemical branch in the global market, it is proposed the constant-market share methodology to chemical exports coupled with econometric analysis. Results. The constant market share (CMS) approach to assessing competitiveness, developed in the $1970 \mathrm{~s}$ for analysis of trade, is based on the principle that changes in the geographic and product structures of exports will affect a country's export growth relative to that of the world, and that is way its global export market share. There were analyzed the EU biggest exporters (Germany, France, Italy, UK, Spain, Netherlands, Belgium, Poland), the USA, Japan; China, India, Saudi Arabia, Brazil. Practical implication. The analysis presents the results of competitiveness assessment in a different way, showing the average annual growth rate of EU and world chemical exports in the top section and then decomposing the gap between the two into that thanks to growth dynamics (structure effect) and competitive effect. It is defined a lot of factors that are important to industrial competitiveness. On the cost side, in many industries labor is a large enough share of overall production costs that international differences in salaries can have a large bearing on competitiveness. Costs are also affected by a variety of government policies. It is also defined that innovation is one of the most important factors, which opens up new opportunities both in terms of new products and more efficient processes for manufacturing existing products. Value/originality. Given analysis helps to understand the causes and factors that have an impact on the European chemicals competitiveness what gives an opportunity to make forecasts and prospects of the future development of this sector.
\end{abstract}

Key words: chemicals competitiveness, global manufacturing, constant market share, international comparison, competitive effect.

JEL Classification: F 14, F 17, L 65.

\section{Introduction}

The chemical industry is one of the EU's most successful spheres, boasting $€ 527$ billion in sales in 2013, making it the second-largest global manufacture. But in spite this strength, the current situation appears to be cause for worry The chemical branch was affected by the 2008-09 global crisis, and after a rapid cyclical turnaround, production has stagnated since 2011. Over a longer time horizon, the EU's share of global exports has fallen sharply, suggesting a decline in competitiveness, amongst other factors.

In order to understand the competitive performance of the EU chemical branch in the global market, Oxford Economics has applied the constant-market share methodology to chemical exports coupled with econometric analysis (Oxford Economics, 2014).

Using constant-market share analysis of chemical exports at the aggregate and subsector level for the $\mathrm{EU}$ and some other large developed and developing countries that are significant chemical exporters, this paper bears out that the majority of the decrease in extra-EU export market share observed over the past 20 years (including that since the 2008-09 financial crisis) is thanks to declining competitiveness as opposed to slow-growing destination markets. Falls have also been seen in other developed countries at the expense of China and Saudi Arabia, albeit the magnitude of the European decline is larger than that of the USA. The decline has been driven by petrochemicals and polymers (Competitiveness, 2015).

Because of the erosion of competitiveness, the $\mathrm{EU}$ has slipped from number three to four out of seven leading global exporters with regard to absolute levels of competitiveness (Landscape, 2014) Within the EU, the countries with the highest level of competitiveness are the Belgium, Netherlands and Germany, while Poland and Spain have leapt in the rankings at the expense of France and Great Britain. 


\section{Competitiveness assessment methodology}

The constant market share (CMS) approach to assessing competitiveness, developed in the $1970 \mathrm{~s}$ for analysis of trade, is based on the principle that changes in the geographic and product structures of exports will affect a country's export growth relative to that of the world, and that is way its global export market share.

Thus, even if a country maintains its export share in destination markets and spheres it serves, if demand in those countries and sectors is growing slowly than the average, its global export market share will fall.

In theory, this has to mean that if one corrects for the fact that a country's export product mix and geographic distribution is different from the average, its export growth should equal world export growth, thus maintaining a "constant market share" of exports in markets and spheres it serves (Alliance, 2014).

In practice, a country's export growth differs from the world even after accounting for the structural effect. This difference is termed the competitiveness effect, and it measures change in market share in the destination markets and spheres that the country serves. If this is falling it is assumed to indicate a reduction in competitiveness and conversely.

The great strength of the given approach is its ability to decompose export growth into that driven by global growth trends (which are beyond the direct control of individual countries) and that thanks to national competitiveness (which can be influenced by economic policies). It provides a useful and easy-to-understand way of gauging the extent to which trade performance is driven by external and internal factors. Other measures of changes in competitiveness, such as movements in the trade balance, don't have this ability.

Strength is that the indicators are consistent across countries, thus facilitating international comparisons. Besides, export data quality is good compared to other indicators because of the administrative information that needs to be collected when products cut across national borders.

A final strength is the granularity of the information about sectors. It is conducted the analysis in five subsectors of chemicals for the EU and six other countries.

Analyzing countries:

EU: Defined as aggregate of 8 biggest exporters (Germany, France, Italy, UK, Spain, Netherlands, Belgium, Poland), accounting for over $90 \%$ of extra-EU exports;

Developed countries: US, Japan;

Developing countries: China, India, Saudi Arabia, Brazil.

Subsectors: petrochemicals, polymers, basic inorganics, specialty chemicals, consumer chemicals (Chemical connections, 2015).

The Fig. 1 shows the evolution of the EU's export market share.

The given graphic shows the instability of the chemicals export of the EU. We can see that the EU's global export market share dipped in the early $1990 \mathrm{~s}$ but then recouped

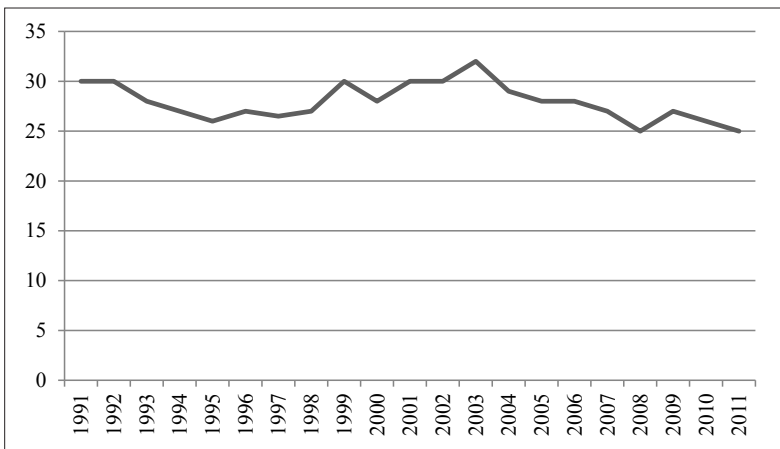

Source: (Oxford Economics, 2014, see p. 6)

Fig. 1. The EU chemicals market share in 1991-2011, \%

those losses later in the decade, with the movements driven by changes in competitiveness. Since 2003 it has fallen steadily, with the majority of this fall thanks to declining competitiveness rather than slower-growing export markets.

The Table 1 presents the results of competitiveness assessment in a different way, showing the average annual growth rate of EU and world chemical exports in the top section and then decomposing the gap between the two into that thanks to growth dynamics (structure effect) and competitive effect.

Table 1

The results of the EU competitiveness assessment

\begin{tabular}{|c|c|c|c|}
\hline Periods & $1992-2000$ & $2000-2008$ & 2008-2014 \\
\hline & \multicolumn{3}{|c|}{ Average annual growth rate, $\%$} \\
\hline $\begin{array}{l}\text { Growth of the EU } \\
\text { chemical exports }\end{array}$ & 9,7 & 10,8 & 5,3 \\
\hline \multirow{2}{*}{$\begin{array}{l}\text { Growth of World } \\
\text { chemical exports }\end{array}$} & 9,6 & 13,6 & 10,6 \\
\hline & \multicolumn{3}{|c|}{ Percentage points, $\%$} \\
\hline $\begin{array}{l}\text { Difference between } \\
\text { World and EU export } \\
\text { growth }\end{array}$ & 0,2 & $-2,7$ & $-5,3$ \\
\hline Due to Structure effect & 0,3 & $-0,8$ & $-1,5$ \\
\hline Due to Competitive effect & $-0,2$ & $-1,9$ & $-3,9$ \\
\hline
\end{tabular}

Source: (Oxford Economics, 2014, see p. 6)

As we can see, in the post- crisis period, average annual EU chemical export growth was 5,3 percentage points less the $10,6 \%$ rise in world exports, and it is seen that this gap was thanks to worsening competitiveness, though slowergrowing markets were an important reason too.

\section{International prospects of the EU chemicals competitiveness}

Trade in chemicals is large business: total world exports excluding intra-EU trade rose nearly sevenfold to $€ 525$ billion from 1995 to 2014. For comparison, non-EU chemical manufacturing reached $€ 2.7$ trillion in 2014, implying that about $20 \%$ of production is exported. The EU remains the second-largest chemical exporter after the USA and ahead of Japan (and would be the largest if intra-EU trade were included). In spite of it, there are 
some dramatic changes in these shares over the past 20 years. The EU's share has fallen to $18 \%$ (smaller than the declines in the USA) at the expense of dramatic increases in developing countries. The goal is to describe and understand these tendencies.

In the $1990 \mathrm{~s}$, there were dramatic changes in the European economy. In the first part of the decade, market share fall in the wake of the collapse of the Soviet Union and reunification of Germany, both of which imposed adjustment costs on Germany particularly and had indirect adverse effects on other countries of Western Europe (Energy policy, 2013).

But the strengthened connections between Eastern and Western Europe worked to the eventual benefit of nations such as the Czech Republic and Poland. After a period of adjustment during which they moved to more marketoriented economies and modernized their industrial capacity, they could offer chemicals of comparable quality but with significantly lower wages and production costs. Thus put pressure on Germany, the United Kingdom and other large exporters within Europe, but also helped the EU improve its export market share in the $1990 \mathrm{~s}$.

Besides, the global economy picked up considerable momentum in the end of $1990 \mathrm{~s}$, in particular in the USA, where industrial production rose $5.1 \%$ annually in 1995 2000. As the US is the main market, this gave a boost to European exporters and contributed to a recovery of market share. By the late $1990 \mathrm{~s}$, exchange rate integration was underway with the introduction of the euro as an accounting unit on January 1, 1999 and as a currency in 2002. The euro weakened significantly in the two years after its launch. The effect on the cost of exports may have helped support the EU's global export market share in the 2000 s beginning (European chemistry, 2013).

Subsequent to that competitive pressures started to mount with the accession of China to the WTO in December 2001. As China gained expanded access to international markets and continued its rapid process of industrialization and development of low-cost producing, the EU's share of chemical exports began a sharp decline.

In the wake of the 2008-2009 global financial crisis, the EU share slid further, partly thanks to a recovery in its key markets (the USA and non-EU Europe), but mainly thanks to a further deterioration of competitiveness.

\section{The EU comparison with the developed countries}

The USA, as the EU, has had a considerable fall in market share, and the large majority is because of declining competitiveness. The damage had been done by the mid$2000 \mathrm{~s}$.

Later, export competitiveness has stabilized. As said earlier, the EU is not alone among developed countries in facing competitive pressures in the chemical sector. Japan demonstrates a completely different pattern, which shows the advantage of being located near a high-growth region. Its actual global export market share has fallen significantly less than that of the USA, and about as much as the EU's share. But the reason for this is not better competitiveness; rather, it is the structural effect of growth dynamics. Japan has become a key exporter to China, which has the most rapid industrial manufacturing growth in the world, and accounting for this would have implied an increase in market share in the $2000 \mathrm{~s}$. In essence, proximity to growing markets is helping offset a large and growing competitiveness gap in Japan.

\section{The EU comparison with the developing countries}

Chemicals export market shares are on the rise across the developing world, but as in the developed world, there are contrasts in trends over time. The fastest increase is in China, where market share increased fourfold to exceed that of Japan by 2014 by a comfortable margin. This rise is evident across most subsectors, illustrating the development of a diversified chemical sector in China. Most of the increase in market share occurred after China's entry into the WTO in 2001. The structural effect was flat to negative in the $1990 \mathrm{~s}$ and $2000 \mathrm{~s}$, showing the fact that one of China's largest destination markets during that time was Japan, which was dealing with two decades of deflation and poor economic growth. Since the financial crisis, it has focused its attention on India and other Asian markets, resulting in a positive structural effect. Nonetheless the large share of the increase in market share is because of increasing competitiveness. Similar patterns are evident in India, though the scale is smaller.

Saudi Arabia's export market share has rose as well, with all of it occurring within the past seven years. The spike in 2008 is undoubtedly because of the opening of a plant that serves export markets but the increase has continued in the post-crisis years. Unlike for China, the increase is concentrated in petrochemicals and polymers; other spheres have low export market shares and have not seen any significant increases over the sample period. Furthermore, a bigger proportion of the rise in market share is explained by growth in destination markets, albeit the improvement in competitiveness is substantial as well.

Brazil is a different story, where export market share ( $1 \%$ of world exports in 1992) has struggled to rise. There was a slight rise in the mid-2000 s as the government of Lula da Silva implemented structural reforms designed to support the business environment. Since then reform has stalled and the tangle of red tape, regulation, and taxes known as the "custo Brasil" has stymied further improvements in competitiveness.

\section{Potential drivers of the chemical competitiveness}

There is a long literature on the factors that are important to industrial competitiveness, and many of them are important not only for the chemical industry but for the whole spheres of tradable goods. Because competitiveness 
is about offering superior customer value at an attractive price, all drivers are in one way or another connected with the production costs or product quality.

On the cost side, in many industries labor is a large enough share of overall production costs that international differences in salaries can have a large bearing on competitiveness, and is one of the causes that some industries, such as mass-market apparel, have migrated to the developing world over the past decades.

While the chemical industry is less labor intensive than producing as a whole, there is reason to believe that labor costs may nonetheless matter. Another cost that is important in the chemicals industry is energy and raw materials costs. The chemical branch is the most energyintensive of all producing sectors: in the EU, it accounts for $20 \%$ of industrial energy using, well above its $7 \%$ share of producing output. For certain subsectors like petrochemicals and basic inorganics, energy and feedstock costs are larger than payroll costs, so it is expected this to be very important - indeed evidence from the USA shale gas boom is suggestive in this regard.

Exchange rates also influence the cost of goods purchased by foreign consumers, and macroeconometric research demonstrates that a weaker currency tends to be followed acceleration of export growing. It is expected the same to be true in the chemicals industry, though the impact of higher import prices could have an offsetting impact in subsectors that are important importers of raw materials.

Costs are also affected by a variety of government policies. On the negative side, burdensome tax systems reduce after-tax profits (and the resources to invest in activities that support competitiveness) and also increase compliance costs. Similarly, regulations, if not well structured, increase the resources that companies must devote to compliance and, in some cases, have unintended consequences that stymie new product development and innovation (CEFIC, 2015).

On the positive side, governments have an important role to play in the development and quality of infrastructure such as transport networks, with roads being the most important with respect to international trade. To the extent that it reduces transportation costs, complements private business investment and promotes supply chain breadth, the quality of a country's infrastructure can enhance competitiveness.

With regard to product quality, the most important factor is innovation, which opens up new opportunities both in terms of new products and more efficient processes for manufacturing existing products. The internet is the archetypal example, having spawned not only new products, but new industries. But the chemical sector is also rife with examples of wider innovation impacts, such as lightweight materials for automotive and aerospace efficiency, development of cleaner-burning fuels, and others.

\section{Conclusions}

It is analyzed historical trends and development prospects of the European chemical industry competitiveness. It is concluded that the chemical industry is one of the EU's most successful spheres, boasting $€ 527$ billion in sales in 2013, making it the second-largest global manufacture.

To explain the competitiveness of the EU chemical branch in the global market, it is proposed the constantmarket share methodology to chemical exports coupled with econometric analysis. The constant market share (CMS) approach to assessing competitiveness, developed in the $1970 \mathrm{~s}$ for analysis of trade, is based on the principle that changes in the geographic and product structures of exports will affect a country's export growth relative to that of the world, and that is way its global export market share.

The strength of the approach is the ability to decompose export growth into that driven by global growth trends and that thanks to national competitiveness (which can be influenced by economic policies). It provides a useful and easy-to-understand way of gauging the extent to which trade performance is driven by external and internal factors. There were analyzed the EU biggest exporters (Germany, France, Italy, UK, Spain, Netherlands, Belgium, Poland), the USA, Japan; China, India, Saudi Arabia, Brazil.

The analysis presents the results of competitiveness assessment in a different way, showing the average annual growth rate of EU and world chemical exports in the top section and then decomposing the gap between the two into that thanks to growth dynamics (structure effect) and competitive effect.

It is defined a lot of factors that are important to industrial competitiveness, and many of them are important not only for the chemical industry but for the whole spheres of tradable goods. On the cost side, in many industries labor is a large enough share of overall production costs that international differences in salaries can have a large bearing on competitiveness, and is one of the causes that some industries, such as mass-market apparel, have migrated to the developing world over the past decades.

Exchange rates also influence the cost of goods purchased by foreign consumers, and macro-econometric research demonstrates that a weaker currency tends to be followed acceleration of export growing.

Costs are also affected by a variety of government policies. On the negative side, burdensome tax systems reduce after-tax profits (and the resources to invest in activities that support competitiveness) and also increase compliance costs. On the positive side, governments have an important role to play in the development and quality of infrastructure such as transport networks, with roads being the most important with respect to international trade.

It is also defined that innovation is one of the most important factors, which opens up new opportunities both in terms of new products and more efficient processes for manufacturing existing products. 


\section{References}

Alliance for competitive European industry (2014). Retrieved September 8, 2015 from http://www.cefic.org/ Documents/PolicyCentre/Competitiveness/Shifting-Gears-for-New-EU-Industrial-Partnership-Manifesto.pdf CEFIC (2015). Impact of lower oil price on the European Chemical Industry. Retrieved September 5, 2015 from http://www.cefic.org/Documents/PolicyCentre/Competitiveness/Impact-of-lower-oil-price-on-the-EuropeanChemical-Industry.pdf

Chemical connections. (2015). How opening up chemicals trade can boost growth and jobs in Europe. Retrieved September 5, 2015 from http://www.cefic.org/Documents/PolicyCentre/Competitiveness/ChemicalConnections.pdf

Competitiveness of the European chemical industry (2015). How to regain ground in the global market. Retrieved September 4, 2015 from http://www.cefic.org/Documents/PolicyCentre/Competitiveness/Competitiveness-ofthe-European-chemical-industry-2014.pdf

Energy policy at the crossroads (2013). Finding the road to a competitive, low carbon and energy efficient Europe. Retrieved September 8, 2015 from http://www.cefic.org/Documents/PolicyCentre/ETS/Energy-Roadmap-TheBrochure-Energy-policy-at-the-crossroads.pdf

European chemistry for growth (2013). Unlocking a competitive, low carbon and energy efficient future Retrieved September 8, 2015 from http://www.cefic.org/Documents/PolicyCentre/ETS/Energy-Roadmap-The\%20 Report-European-chemistry-for-growth.pdf

Landscape of the European Chemical Industry (2014). Retrieved September 5, 2015 from http://www.cefic. org/Documents/Landscape-European-chemical-industry/Landscape-of-the-European-Chemical-IndustryMarch-2014.pdf

Oxford Economics (2014). Evolution of competitiveness in the European chemical industry: historical trends and future prospects. Retrieved September 3, 2015 from http://www.cefic.org/Documents/PolicyCentre/ Competitiveness/Oxford-Study-2014.pdf

\section{Дмитрий ГЛАДКИХ}

\section{КОНКУРЕНТОСПОСОБНОСТЬ ЕВРОПЕЙСКОЙ ХИМИЧЕСКОЙ ПРОМЫШЛЕННОСТИ: ИСТОРИЧЕСКИЕ ТЕНДЕНЦИИ И ПЕРСПЕКТИВЫ РАЗВИТИЯ}

Аннотация. Целью статьи является анализ исторических тенденций и перспектив развития конкурентоспособности европейской химической отрасли промышленности. Получены выводы, что химическая промышленность ЕС является наиболее успешной сферой, прибыль которой в 2013 году составила 527 млрд. евро, став второй крупнейшей глобальной отраслью. Методология. Для объяснения конкурентоспособности химической отрасли промышленности ЕС на глобальном рынке предложена методика расчета постоянной рыночной доли экспорта химической продукции, а также эконометрический анализ. Результаты. Предложенная методика, развитая в 1970-х гг. для анализа торговли, базируется на принципе, что изменения географической и товарной структур экспорта влияют на рост экспорта страны, что в итоге влияет на экспортную долю на глобальном рынке. Были проанализированы крупнейшие экспортеры ЕС (Германия, Франция, Италия, Великобритания, Испания, Нидерланды, Бельгия, Польша), США, Япония, Китай, Индия, Саудовская Аравия, Бразилия. Практическое значение. Анализ показывает результаты оценки конкурентоспособности различными способами, отражая средний уровень увеличения доли стран ЕС в глобальном экспорте химической продукции, а также динамику структурных эффектов и эффектов конкуренции. Определено несколько факторов, которые влияют на конкурентоспособность химической отрасли. С затратной стороны важно выделить оплату труда, которая значительно влияет на конкурентоспособность отрасли. Также важно отметить характер политики, проводимой государством. Не менее значимым фактором являются инновации, которые открывают новые возможности для производства новой продукции и новых процессов, способных улучшить качество уже существующих продуктов. Значение/оригинальность. Данный анализ помогает понять причины и факторы, которые влияют на конкурентоспособность химической отрасли ЕС, что дает возможность прогнозировать перспективы будущего развития данного сектора. 